\title{
A Validated RP-HPLC Method for the Determination of Recombinant Human Insulin in Bulk and Pharmaceutical Dosage Form
}

\author{
B. A. MOUSSA, F. FAROUK* and H. M. E. AZZAZY ${ }^{\S}$ \\ Department of Pharmaceutical Chemistry \\ Faculty of Pharmacy, Cairo University, Cairo, Egypt \\ *Egyptian Company of Biological Products and Vaccines (VACSERA), Giza, Egypt \\ ${ }^{\S}$ Department of Chemistry, American University in Cairo, New Cairo, Egypt \\ fatenfarouk@aucegypt.edu
}

Received 9 February 2010; Revised 21 April 2010; Accepted 1 May 2010

\begin{abstract}
A modified RP-HPLC method was developed for the quantitative determination of recombinant human insulin in bulk and pharmaceutical dosage form with reduced retention time. Study of the effects of the column temperature, $\mathrm{pH}$ of the mobile phase and presence of vial additives (phenol and $m$-cresol), or impurities (A-21 Disamido) on the accuracy of the assay were assessed. Separation was achieved using a Hypersil BDS C-18 column and the mobile phase was composed of solution A (aqueous solution of 28.3 anhydrous $\left.\mathrm{Na}_{2} \mathrm{SO}_{4} \mathrm{~g} / \mathrm{L}, \mathrm{pH} 2.3\right)$ and solution $\mathrm{B}\left(28.5 \mathrm{~g}\right.$ anhydrous $\mathrm{Na}_{2} \mathrm{SO}_{4} \mathrm{~g} / \mathrm{L}$ in 50:50 mixture of water and acetonitrile, $\mathrm{pH} 2.3)$ in a ratio $48: 52(\mathrm{v} / \mathrm{v})$ at $45-$ $50{ }^{\circ} \mathrm{C}$. The column temperature was $40^{\circ} \mathrm{C}$, the flow rate was $1 \mathrm{~mL} / \mathrm{min}$ and detection was performed at $216 \mathrm{~nm}$. The procedures were validated according to international conference on harmonization (ICH) guidelines. Recovery study was done applying standard addition technique for further validation of the procedure. The retention time of recombinant human insulin was $19.7 \mathrm{~min}$ as compared to 29 min obtained by the reference method. Analytical conditions fluctuations or presence of vial additives or impurities did not show any significant effect on the accuracy of the method. The prepared standard insulin solution in $0.01 \mathrm{~N} \mathrm{HCl}$ was found to be stable for 5 days. Statistical comparison showed no significant difference between the described method and reference method regarding the accuracy and precision. The modified method can be applied for routine quality control applications for determination of recombinant human insulin.
\end{abstract}

Keywords: RP-HPLC, Recombinant human insulin, Quantitative, Validation, Effect of additives, Impurities. 


\section{Introduction}

Insulin is composed of two peptide chains, referred to as A chain (21 amino acids) and B chain (30 amino acids) with molecular weight of $5.8 \mathrm{kDa}$. Two disulfide bridges link these chains together and another intra-peptide disulfide bond exists in the A chain ${ }^{1,2}$. Human insulin produced by recombinant DNA technology is the first commercial health care product derived from this technology. A weakened form of Escherrichia coli is used as a vector for the synthesis of recombinant human insulin. The protein is produced in the bacterial cell as two chains A and B. The two chains are mixed and reconnected in a reaction that forms the disulfide cross bridges, resulting in pure recombinant human insulin. Insulin is administered subcutaneously for the treatment of type I diabetes mellitus when pancreatic $\beta$-cells daily production of insulin is insufficient. Several methods have been reported for the determination of insulin in the pharmaceuticals and plasma including voltametric ${ }^{3}$, spectroscopic $^{4}$, electrochemical ${ }^{5}$ and chromatographic methods ${ }^{6,7}$.

RP-HPLC is probably the most used analytical method for separation and determination of peptides and proteins in an extensive range of applications ${ }^{8}$. The United States Pharmacopeia (USP) describes a RP-HPLC method for the determination of recombinant human insulin with insulin peak detected at $214 \mathrm{~nm}$ and appearing ${ }^{9}$ after $29 \mathrm{~min}$. The aim of the present study is to provide a RP-HPLC method suitable for industrial application with reduced analysis time that can withstand fluctuations in analytical conditions, presence of vial additives (phenol and $\mathrm{m}$ cresol) or impurities (A-21 disamido) without significant effect on its accuracy.

\section{Experimental}

Chromatographic separation was performed on Shimatzu 2010 HPLC system (Germany) equipped with an auto-sampler, a Hypersil BDS C-18 $(30 \times 4.6 \mathrm{~mm}, 3 \mu \mathrm{m})$ column and a UV detector. A Kontes Ultra-Ware ${ }^{\circledR}$ filtration system with 5 liter reservoir part no. 31862(USA) was used.

\section{Pure standards}

Recombinant human insulin USP reference standard and bulk crystals were obtained from the egyptian company for biological products and vaccines (VACSERA, Egypt).

Pharmaceutical dosage forms of insulin

Commercially available insulin-VACSERA $\mathrm{R}^{\circledR} 40$ IU was obtained from public pharmacy.

\section{Chemicals and reagents}

All chemicals and reagents used throughout this work were of analytical grade and the solvents were of HPLC grade. Water for injection (WFI) was obtained from VACSERA (Egypt). Hydrochloric acid, o-phosphoric acid, sodium sulphate, acetonitrile, phenol and $m$-cresol were obtained from Fisher (USA).

\section{Standard solutions}

\section{Recombinant human insulin standard solutions}

Into a series of $50 \mathrm{~mL}$ volumetric flasks, different concentrations of recombinant human insulin USP reference standards $(20,40,80,90,100,10$ and $120 \mathrm{IU} / \mathrm{mL})$ were prepared by dissolving $35.3 \mathrm{mg}, 70.6 \mathrm{mg}, 141.2 \mathrm{mg}, 158.8 \mathrm{mg}, 176.5 \mathrm{mg}, 194.2 \mathrm{mg}$ and $211.8 \mathrm{mg}$ of the recombinant human insulin USP reference standard crystals, respectively, in $0.01 \mathrm{~N} \mathrm{HCl}$.

\section{Phenol and $m$-cresol standard solution}

In a $50 \mathrm{~mL}$ volumetric flask, $65 \mathrm{mg}$ of phenol and $150 \mathrm{mg}$ of $m$-cresol were dissolved in acetonitrile. This was the manufacturer reported concentration in the final dosage form. 


\section{Preparation of A-21 disamido (degradation product of insulin)}

In a suitable clean capped vial, $1 \mathrm{mg}$ of insulin crystals was dissolved in $1 \mathrm{~mL} 0.01 \mathrm{~N} \mathrm{HCl}$ and incubated at $35^{\circ} \mathrm{C}$ for 4 days ${ }^{9}$.

\section{Insulin, phenol and m-cresol mixture}

In suitable clean capped vials, $5 \mathrm{~mL}$ from the 80, 100 and $120 \mathrm{IU} / \mathrm{mL}$ insulin standard solutions were separately mixed with $5 \mathrm{~mL}$ of the prepared phenol and $m$-cresol standard solution.

\section{Chromatographic conditions}

Chromatographic separation was performed using a Hypersil BDS C-18 (30x4.6 mm, $3 \mu \mathrm{m})$ analytical column. The flow rate was maintained at $1 \mathrm{~mL} / \mathrm{min}$ and the detection was performed at $216 \mathrm{~nm}$. The column temperature was kept at $40{ }^{\circ} \mathrm{C}$. The mobile phase consists of solution A and B of $\mathrm{pH} 2.3$ in a ratio of $48: 52(\mathrm{v} / \mathrm{v})$ at $45-50^{\circ} \mathrm{C}$.

\section{Preparation of mobile phase}

Solution A was prepared by dissolving $56.8 \mathrm{~g}$ of anhydrous $\mathrm{Na}_{2} \mathrm{SO}_{4}$ in WFI then the $\mathrm{pH}$ was adjusted to 2.3 with $o$-phosphoric acid and the volume was completed to $2 \mathrm{~L}$ with WFI and filtered. Solution B was prepared by dissolving $28.5 \mathrm{~g}$ of $\mathrm{Na}_{2} \mathrm{SO}_{4}$ in $400 \mathrm{~mL} \mathrm{WFI}$, the $\mathrm{pH}$ was adjusted to 2.3 with $o$-phosphoric acid, volume was completed with WFI to $1 \mathrm{~L}$ then $1 \mathrm{~L}$ of acetonitrile was added. The two solutions (A \& B) were kept on hot-plate magnetic stirrer at a temperature $45-50{ }^{\circ} \mathrm{C}$ with continuous stirring and filtered before being introduced into the HPLC system.

\section{Determination of method specificity}

\section{Identification}

$20 \mu \mathrm{L}$ of $0.01 \mathrm{~N} \mathrm{HCl}, 100 \mathrm{IU} / \mathrm{mL}$ insulin standard, A-21 disamido preparation, phenol \& $m$-cresol were separately injected into the HPLC system and chromatographed under the previously mentioned chromatographic conditions. The retention time for each was recorded.

\section{Assay}

The effect of vial additives was tested by carrying out the experiment on the prepared insulin, phenol and $m$-cresol mixtures. Area under the peak (AUP) corresponding to insulin concentration was recorded for each mixture and insulin recovery percent was calculated using the regression equation as described below (linearity).

\section{Linearity}

A series of different concentrations of recombinant human insulin ranging from 80-120 IU/mL were injected into the HPLC system and analyzed using the specified chromatographic conditions. The retention times and the AUPs were recorded from the resulting chromatograms. A calibration curve plotted for the AUP versus insulin concentration and the respective regression equation was computed.

Accuracy

Different aliquots of insulin standard solutions $(80,100$ and $120 \mathrm{IU} / \mathrm{mL})$ were injected into the HPLC system and the same procedures used for establishing linearity were followed. AUP for each insulin solution was recorded and the recovery percent of insulin was calculated using the regression equation. 


\section{Precision}

Inter-assay precision (Repeatability)

Insulin standard solutions $(80,100$ and $120 \mathrm{IU} / \mathrm{mL})$ were analyzed three times each intradaily. The AUPs were recorded and the relative standard deviation (RSD) was calculated.

\section{Intermediate precision}

Intermediate precision expresses within-laboratory variations including different days, analysts, equipments, etc. According to the International Conference on Harmonization (ICH) guidelines it is not necessary to study these effects individually; the use of an experimental design (matrix) is encouraged ${ }^{10}$. The previous procedures were repeated interdaily (on different days) using different insulin standards concentrations (80, 100 and $120 \mathrm{IU} / \mathrm{mL}$ ) three times each for each concentration using freshly prepared mobile phase prepared by another analyst. The AUPs were recorded and RSD was calculated.

\section{Limit of detection (LOD) and limit of quantitation (LOQ)}

LOD and LOQ were calculated based on the standard deviation of the analytical response represented by AUP and the slope of the calibration curve. The following equations $\mathrm{LOD}=3.3 \sigma / \mathrm{S}, \mathrm{LOQ}=10 \sigma / \mathrm{S}$ were used, where $\sigma$ is the standard deviation of the response and $\mathrm{S}$ is the slope of the calibration curve.

\section{Robustness}

To determine the robustness of the method, small variations in the experimental conditions were introduced and the AUP was recorded followed by calculation of the RSD. In the above mentioned experiments, the $\mathrm{pH}$ of the mobile phase was 2.3 and the temperature of the column was $40{ }^{\circ} \mathrm{C}$. The effect of small variations in $\mathrm{pH}$ of the mobile phase and the temperature of the column on the method accuracy were separately tested on the $100 \mathrm{IU} / \mathrm{mL}$ insulin standard solution. The $\mathrm{pH}$ was varied between 2.2 and 2.4 in 0.1 unit increments using $o$-phosphoric acid, while the column temperature was varied between $39^{\circ} \mathrm{C}$ and $41{ }^{\circ} \mathrm{C}$ in $1{ }^{\circ} \mathrm{C}$ increments. The procedure was repeated accordingly, the AUP was recorded and RSD was calculated.

\section{Insulin solution stability}

The stability of the insulin standard preparation was tested by analyzing freshly prepared $100 \mathrm{IU} / \mathrm{mL}$ insulin solution using the modified RP-HPLC method. The prepared solution was stored at $2-8{ }^{\circ} \mathrm{C}$ and analyzed every $24 \mathrm{~h}$ for 5 successive days. The AUPs were recorded and RSD was calculated.

\section{Application of the method to commercial products}

\section{Testing purity of bulk recombinant human insulin from commercial suppliers}

Recombinant human insulin solutions of concentrations $(80-120) \mathrm{IU} / \mathrm{mL}$ were prepared according to their labeled potency as per the supplier's certificate of analysis. The prepared concentrations were analyzed using the modified RP-HPLC, AUPs were recorded and recovery percent of pure recombinant human insulin was calculated using the regression equation.

\section{Application on vial dosage form}

$40 \mu \mathrm{L}$ of $6 \mathrm{~N} \mathrm{HCl}$ were added to a commercial $40 \mathrm{IU} / \mathrm{mL}$ insulin vial to obtain a clear solution which was injected into the HPLC system and analyzed. Recovery study was performed by applying standard addition for further validation of the procedure. 


\section{Results and Discussion}

Figure 1 showed that recombinant human insulin had a peak with retention time of $19.7 \mathrm{~min}$. The insulin peak was resolved from the peaks of the additives (phenol $\& m$-cresol; 6.5 and $9.8 \mathrm{~min}$, respectively) and degradation product (A-21 disamido; $25.8 \mathrm{~min}$ ) (Table 1). The additives had no effect on average recovery percent of recombinant human insulin which was $99.76 \pm 0.15$ (Table 2), hence the proposed method was found to be of sufficient specificity for assay of recombinant insulin.

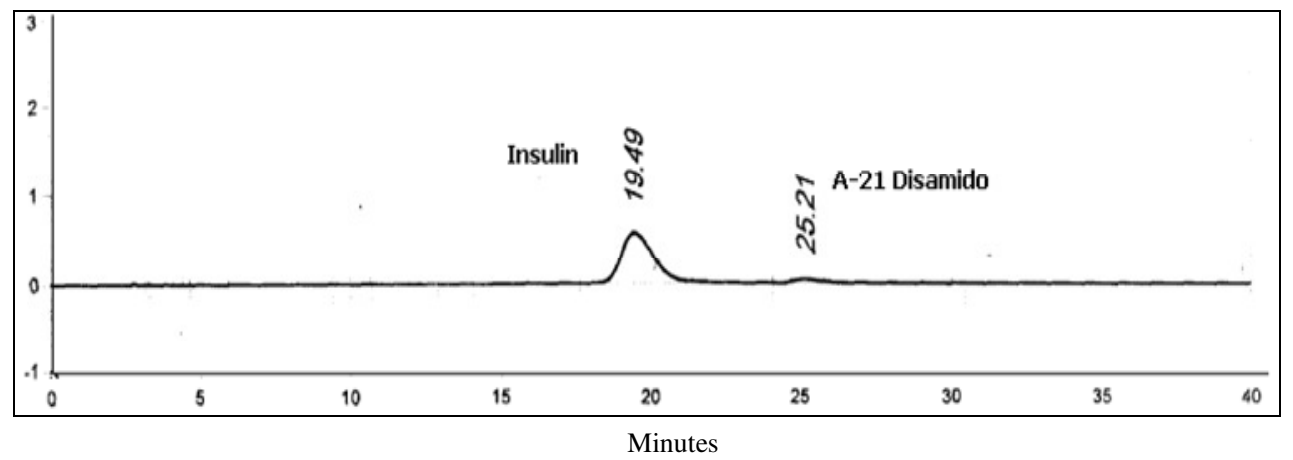

Figure 1. RP-HPLC chromatogram of pure recombinant human insulin (40 IU/mL)

Table 1. Specificity of the insulin RP-HPLC assay

\begin{tabular}{lcc}
\hline \multicolumn{1}{c}{ Sample name } & Average retention time, min & RSD \\
\hline Blank $(0.01 \mathrm{~N} \mathrm{HCl})$ & 3.533 & 0.11 \\
Standard insulin & 19.7 & 0.28 \\
A21-Disamido & 25.892 & 0.8 \\
Phenol & 6.526 & 0.15 \\
$m$-cresol & 9.861 & 1.21 \\
\hline
\end{tabular}

Table 2. Specificity results in presence of vial additives

\begin{tabular}{cccc}
\hline $\begin{array}{c}\text { Concentration of insulin } \\
\text { standard, IU/mL }\end{array}$ & $\begin{array}{c}\text { Mean of AUP } \\
\text { of insulin }\end{array}$ & $\begin{array}{c}\text { Calculated concentration } \\
\text { of insulin, IU/mL }\end{array}$ & $\begin{array}{c}\text { Recovery } \\
\%\end{array}$ \\
\hline 40 & 30071002 & 39.98 & 99.9 \\
50 & 37280943 & 49.9 & 99.8 \\
60 & 44478965 & 59.8 & 99.6 \\
& Average recovery \% & & 99.77 \\
& SD & & 0.15 \\
& RSD & & 0.15 \\
\hline
\end{tabular}

The relationship between AUP and concentration of recombinant human insulin was linear over the concentration range $20-120 \mathrm{IU} / \mathrm{mL}$ and the correlation coefficient was 0.9993. Parameters of the regression equation are shown in Table 3. There was good correlation between AUP and recombinant human insulin concentration.

The AUPs corresponding to insulin concentrations of 80, 90, 100 and 120 IU were used to calculate the recovery percent of insulin using the regression equation. The recovery percent was $99.85 \pm 1.39$ (Table 4). The results demonstrate that the modified method was suitable for quantitative determination of recombinant insulin. 
Table 3. Parameters of regression equation relating insulin concentration to analytical response (AUP)

\begin{tabular}{lc}
\hline \multicolumn{1}{c}{ Parameter } & Value \\
\hline Linearity range & $20-120 \mathrm{IU} / \mathrm{mL}$ \\
Detection limit, IU/mL & 4.17 \\
Quantitation limit, IU/mL & 13.9 \\
Slope of regression equation & 727073 \\
Standard error (SE) of slope & 8777 \\
Confidence limit (CL) of slope & $704512.19-$ to 749634 \\
Intercept & 1002375.65 \\
SE of intercept & 763683.7 \\
CL of intercept & -960735.5 to 2965487 \\
Correlation coefficient & 0.9993 \\
SE & 794751.8 \\
\hline
\end{tabular}

Table 4. Accuracy of the modified RP-HPLC method for determination of recombinant human insulin

\begin{tabular}{|c|c|c|c|c|c|}
\hline $\begin{array}{c}\text { Concentration of } \\
\text { insulin standard, IU/mL }\end{array}$ & AUP & RSD & $\begin{array}{l}\text { Mean of AUP } \\
\text { of insulin }\end{array}$ & $\begin{array}{l}\text { Calculated conc. } \\
\text { insulin, IU/mL }\end{array}$ & $\begin{array}{c}\text { Recovery } \\
\%\end{array}$ \\
\hline & 60197960 & & & & \\
\hline 80 & $\begin{array}{l}59935564 \\
60292500\end{array}$ & 0.307 & 60142004 & 81.34 & 101.67 \\
\hline 90 & $\begin{array}{l}66717900 \\
66795644 \\
66508343 \\
73546600\end{array}$ & 0.227 & 66673962.33 & 90.33 & 100.37 \\
\hline 100 & $\begin{array}{l}72764200 \\
73881451 \\
87294288\end{array}$ & 0.78 & 72764200 & 98.70 & 98.70 \\
\hline 120 & $\begin{array}{l}87156272 \\
87053168\end{array}$ & 0.1 & 87167909.33 & 118.15 & 98.46 \\
\hline \multicolumn{5}{|c|}{ Average recovery $\%$} & 99.8 \\
\hline \multicolumn{5}{|c|}{$\mathrm{SD}$} & 1.51 \\
\hline \multicolumn{5}{|c|}{ RSD } & 1.51 \\
\hline
\end{tabular}

RSDs of analysis for the inter-assay precision $0.3,0.78$ and 0.1 ; and those for the intermediate precision were $0.2,0.2$ and 0.1 for the three chosen concentrations $(80,100 \&$ $120 \mathrm{IU} / \mathrm{mL}$ ) (Table 5).

LOD and LOQ were calculated based on standard deviation of the analytical response represented by AUP and slope of the calibration curve and were 4.17 and $13.9 \mathrm{IU} / \mathrm{mL}$, respectively.

In the robustness study, the effect on AUP was studied and RSDs of the response were 1.8 and 0.6 for $\mathrm{pH}$ of the mobile phase and column temperature variations, respectively. Small fluctuations in analytical conditions had no significant effect on method performance (Table 6). 
Table 5. Precision of the modified RP-HPLC assay for determination of insulin determination

\begin{tabular}{cccccccc}
\hline $\begin{array}{c}\text { Sample } \\
\text { concentration }\end{array}$ & $\begin{array}{c}\text { AUP } \\
\text { for day 1 }\end{array}$ & Average & RSD & $\begin{array}{c}\text { AUP for } \\
\text { day 2 }\end{array}$ & Average & RSD & $\begin{array}{c}\text { Overall } \\
\text { RSD }\end{array}$ \\
\hline \multirow{2}{*}{$80 \mathrm{IU} / \mathrm{mL}$} & $\begin{array}{l}60197960 \\
59935564\end{array}$ & 60142008.0 & 0.30 & $\begin{array}{c}56546831 \\
56291687\end{array}$ & 56413565.00 & 0.2 & 4.5 \\
& 60292500 & & & 56402177 & & & \\
$100 \mathrm{IU} / \mathrm{mL}$ & 73546606 & & & 78988190 & & & \\
& 72764200 & 73397419.0 & 0.78 & 78782067 & 78797103.00 & 0.2 & 4.9 \\
& 73881451 & & & 78621052 & & & \\
$120 \mathrm{IU} / \mathrm{mL}$ & 87294288 & & & 87433128 & & & \\
& 87156272 & 87167909.3 & 0.10 & 87622793 & 87519319.33 & 0.1 & 0.2 \\
\hline
\end{tabular}

Table 6. Effect of $\mathrm{pH}$ of the mobile phase and column temperature variation on the AUP of insulin (Robustness)

\begin{tabular}{crc}
\hline Parameter & Mean AUP & RSD \\
Mobile phase pH & 72193456 & \\
2.4 & 73397417 & 1.8 \\
2.3 & 71920313 & \\
2.2 & & \\
39 & 72474471 & \\
40 & 73397417 & 0.6 \\
41 & 72694456 & \\
\hline
\end{tabular}

In the stability study, the prepared insulin standards were assayed once for 5 consecutive days. The RSD was 0.8 indicating that the standard solution is stable for 5 days (Table 7). This allows the use of the same recombinant insulin standard solution for 5 successive days when stored at temperature $2-8{ }^{\circ} \mathrm{C}$.

Table 7. Stability of standard insulin preparation (100 IU/mL)

\begin{tabular}{ccc}
\hline Day & Mean AUP & Overall RSD \\
\hline 1 & 72193456 & \\
2 & 73397417 & \\
3 & 71920313 & 0.8 \\
4 & 72130189 & \\
5 & 72131716 & \\
\hline
\end{tabular}

The described method was used to quantify insulin in bulk crystals from commercial supplier to determine its purity. Recovery was calculated using the regression equation and results are shown in Table 8.

The method was found applicable to pharmaceutical dosage form with average recovery percent of 100.32 (Figure 2). Recovery study was performed on insulin vial form by applying standard addition technique where known amounts of standards were added to preanalyzed vial samples. The added insulin standard solution was recovered with average accuracy percent of 101.44 \pm 0.896 (Table 9). Statistical comparison between the described method and the USP reference method showed no significant difference with respect to the accuracy and precision of the method (Table 10). 
Table 8. Application of the modified RP-HPLC method for the determination of insulin in bulk crystals from commercial supplier

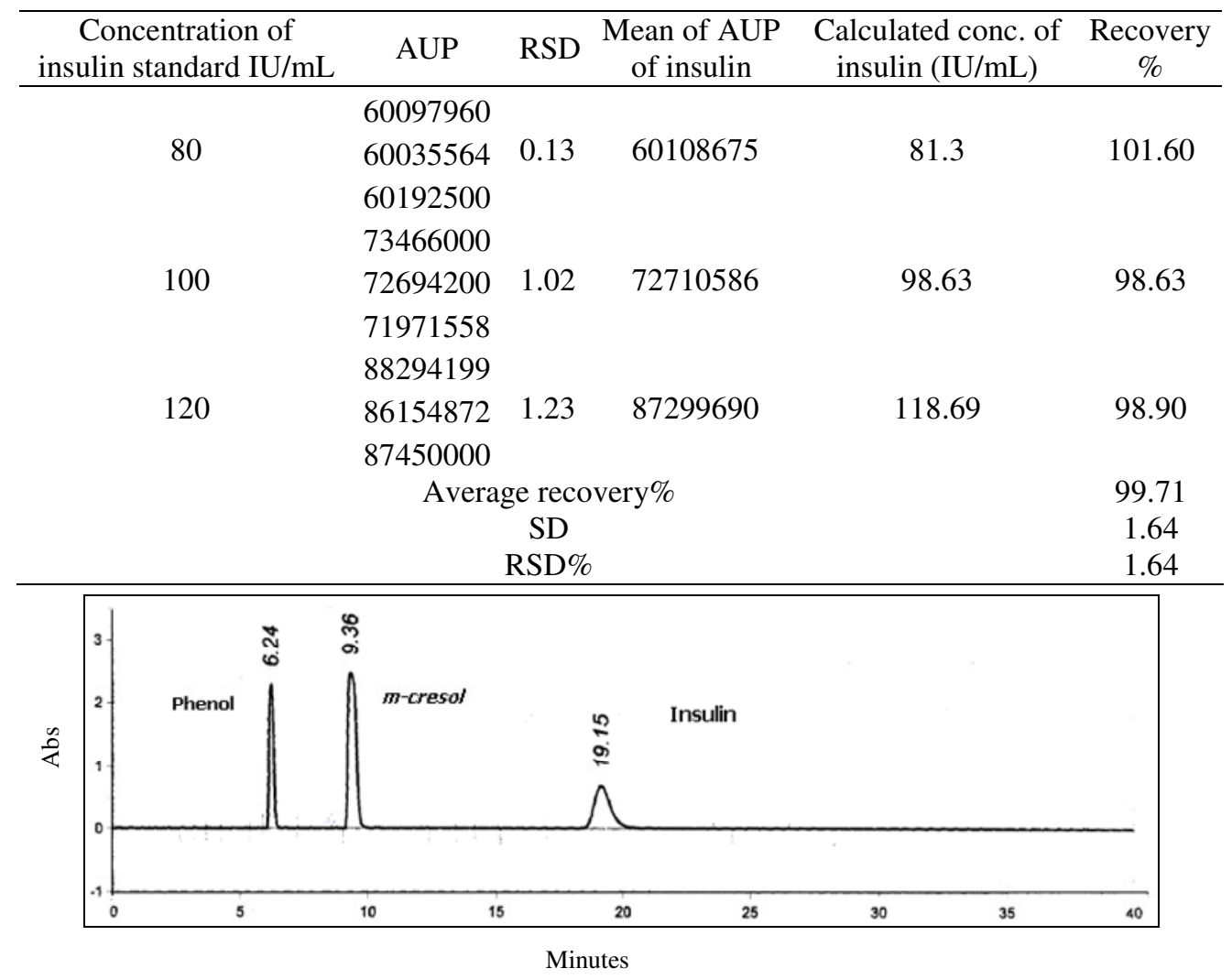

Figure 2. RP-HPLC chromatogram of insulin in vial form. Peaks of phenol, $m$-cresol and insulin appear at 6.24, 9.36 and $19.15 \mathrm{~min}$, respectively.

Table 9. Recovery study of insulin from vial dosage form by applying standard addition technique using the modified RP-HPLC method

\begin{tabular}{|c|c|c|c|c|c|c|c|c|c|c|c|}
\hline $\begin{array}{l}\text { Dosage } \\
\text { form }\end{array}$ & 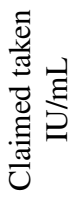 & AUP & 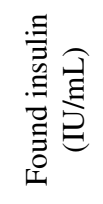 & 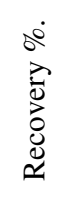 & 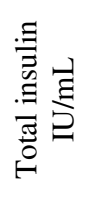 & AUP & 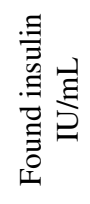 & $\begin{array}{c}\text { Rec. } \\
\%\end{array}$ & 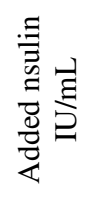 & 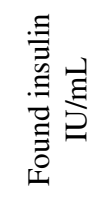 & 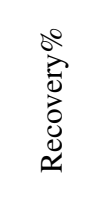 \\
\hline & & & & & 60 & 45369120 & 61.02 & 101.7 & 40 & 40.96 & 102.4 \\
\hline Insulin & & & & & 65 & 48809760.1 & 165.75 & 101.1 & 45 & 45.69 & 101.6 \\
\hline $\begin{array}{c}\text { VACSER } \\
A R^{\circledR}\end{array}$ & 20 & 15585084.3 & 220.06 & 100.3 & 70 & 52257195.1 & 70.49 & 100.7 & 50 & 50.44 & 100.9 \\
\hline $40 \mathrm{IU} / \mathrm{mL}$ & & & & & 75 & 55697735.2 & 75.23 & 100.3 & 55 & 55.17 & 100.3 \\
\hline & & & & & 80 & 60172749.7 & 81.38 & 101.7 & 60 & 61.32 & 102.2 \\
\hline Average & & & & & & & & 101.1 & & & 101.47 \\
\hline SD & & & & & & & & 0.62 & & & 0.88 \\
\hline RSD & & & & & & & & 0.61 & & & 0.87 \\
\hline
\end{tabular}


Table 10. Statistical comparison between the modified and reference RP-HPLC methods for determination of recombinant insulin

\begin{tabular}{ccc}
\hline Recombinant human insulin & Proposed RP-HPLC method & Reference method $^{(6)}$ \\
\hline Accuracy & $99.85 \pm 1.39$ & $99.87 \pm 1.6$ \\
N & 4 & 4 \\
SD & 1.39 & 1.6 \\
RSD & 1.39 & 1.6 \\
Variance & 1.93 & 2.56 \\
F-test & $1.32(9.28)^{*}$ & \\
t-test & $0.019(3.18)^{*}$ & \\
\hline & $* p=0.05$
\end{tabular}

\section{Conclusion}

The objectives of this study were to reduce the analysis time of recombinant insulin using RP-HPLC method and investigate the effect of analytical condition fluctuations and presence of vial additives or impurities on the accuracy of modified method. This is in order to make the RP-HPLC method more amenable for routine quality control procedures of bulk crystals, in-process quality control and finished product analysis.

The retention time of recombinant insulin was $19.7 \mathrm{~min}$ as compared to $29 \mathrm{~min}$ obtained by the reference method. Analytical conditions fluctuations or presence of vial additives or impurities did not show any significant effect on the accuracy of the modified method. The insulin standard was found to be stable for 5 days and validation experiments were satisfactory for all parameters tested.

The modified RP-HPLC method for determination of recombinant human insulin can be applied for routine quality control procedures with no interference from vial additives or impurities and can withstand normal fluctuation in the analysis conditions that may arise during extended operation of the HPLC system.

\section{References}

1. Campbell M K and Farrell S O, Biochemistry; $5^{\text {th }}$ Ed., Thomson Brooks/Cole : Belmont, California, 2006, 684.

2. Dodson $\mathrm{G} \mathrm{G}$ and Whittingham $\mathrm{J}$ L, Insulin \& related proteins: structure to function and pharmacology; Dieken M L, Federwisch M and De Meyts P Ed., Kluwer Academic Publisher: AZ Dordrecht, 2002, 30.

3. Terent'eva S V, Matolygina E M, Aptekar V D, Gusakova A M, Ivanovskaya E A and Teplyakov A T, Pharm Chem J., 2004, 38(7), 401-403.

4. Thevis M, Thomas A and Schanzer W, Mass Spectrom Rev., 2008, 27(1), 35-50.

5. Pikulski M and Gorski W, Anal Chem., 2000, 72(13), 2696-2702

6. Rajan DS, Gowda KV, Mandal U, Ganesan M, Bose A, Sarkar A K and Pal T K, Indian J Pharm Sci., 2006, 68(5), 662-665.

7. Khaksa G, Nalini K,Bhat M and Udupaa N, Anal Biochem., 1998, 260(1), 92-95.

8. Aguilar M, HPLC of Peptides and Proteins: Methods and Protocols; Aguilar M, Ed., Humana press: Totowa , 2004, 251, 3.

9. The United States Pharmacopoeia/National Formulary. USP $30^{\text {th }} /$ NF 25, New York, Twinbrooke Parkway, 2007, p 1375

10. International Conference on Harmonization, (ICH) Q2B, Validation of Analytical Procedures, Methodology, May 1997. 


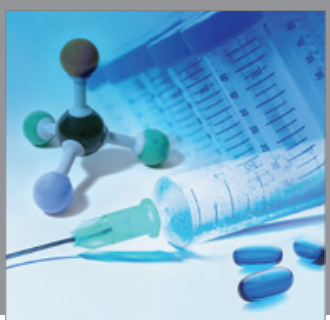

International Journal of

Medicinal Chemistry

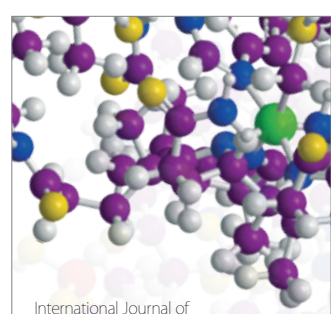

Carbohydrate Chemistry

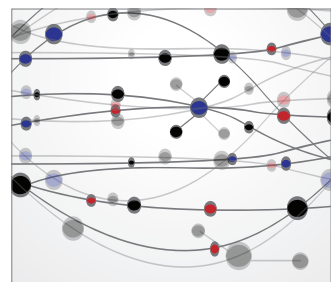

The Scientific World Journal
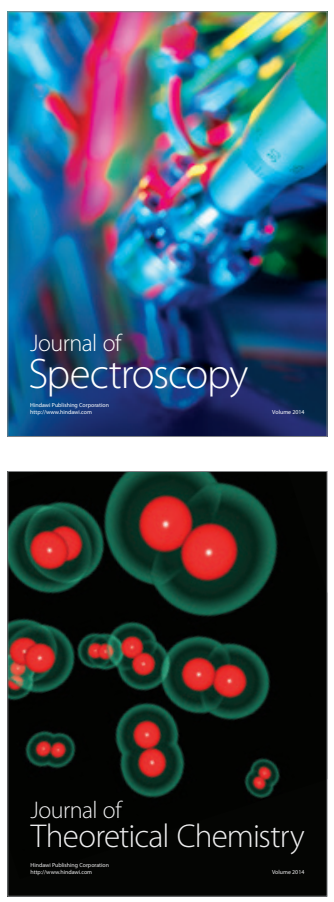
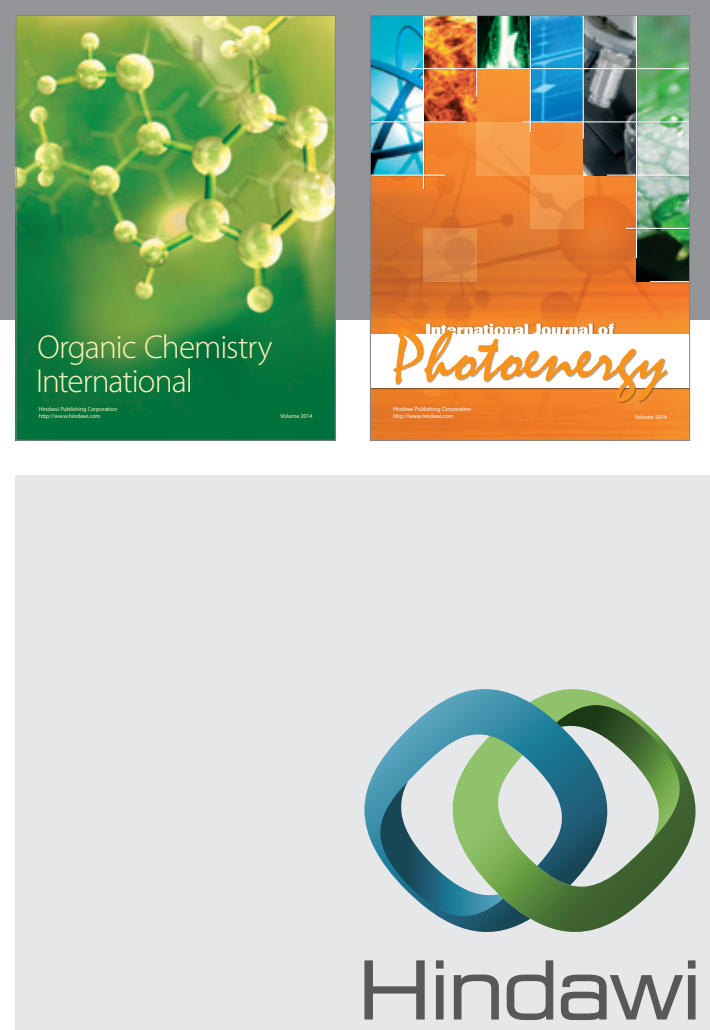

Submit your manuscripts at

http://www.hindawi.com
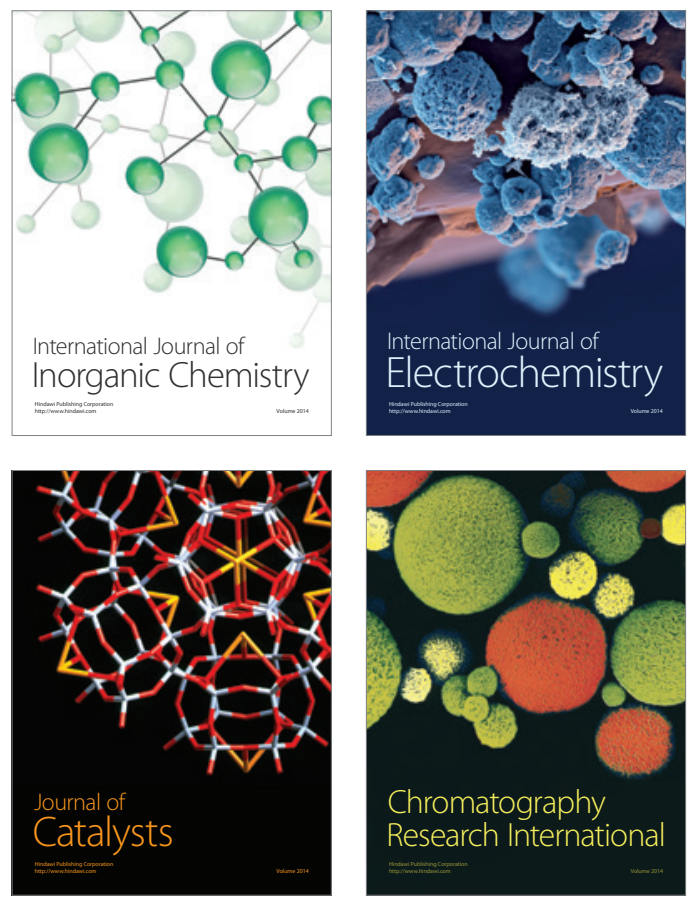
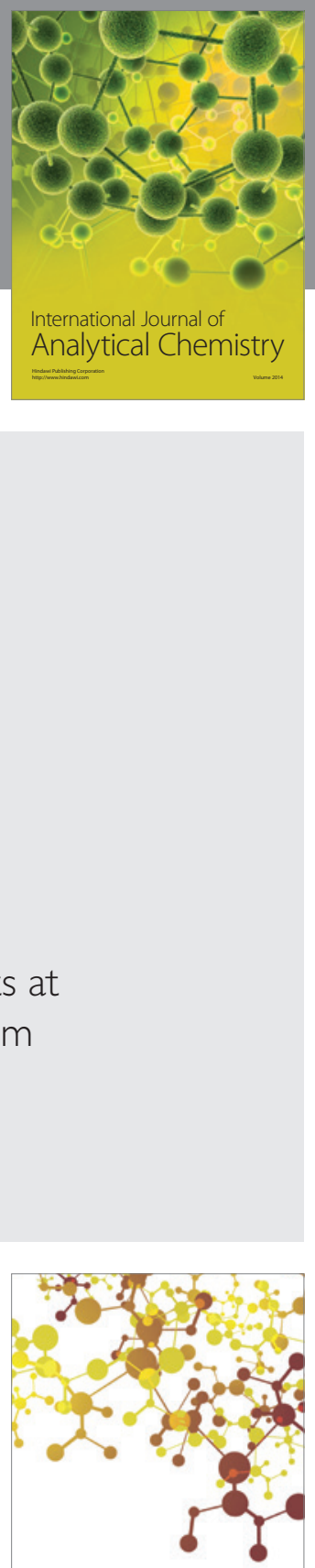

Journal of

Applied Chemistry
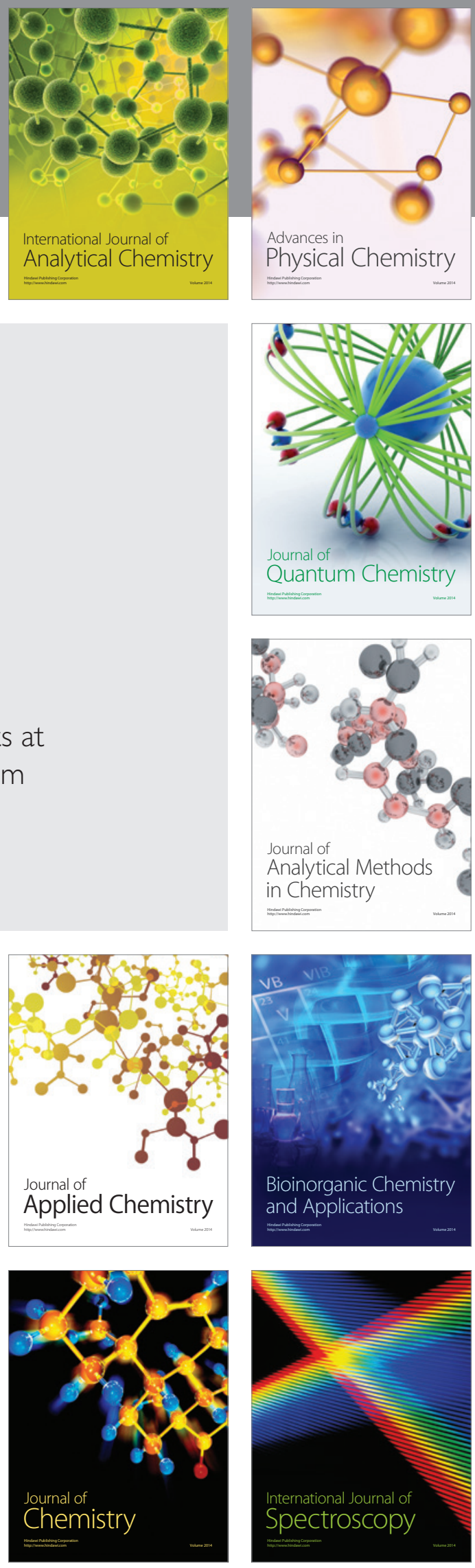